Eddie Woodward

\title{
Building relationships
}

\section{The university archives, the university archivist, and the university's alumni}

$\mathbf{R}$

ecent research is confirming what university archivists and library administrators, as well as university foundation and development officers had long suspected: strategically promoting alma mater history, heritage, and tradition is an easy way to connect or reconnect with alumni. A significant portion of a college or university archivist's responsibilities involves (or should involve) promoting donor/alumni relations, and archivists have found that it is not only important to document and preserve the history of the institution, but also to promote and celebrate that history to its alumni. The university archivist should strive to get alumni interested, involved, and invested in the activities of the archive, ultimately making them stakeholders in the program and its success. This can only be achieved and sustained by building relationships with the former students of the university. ${ }^{1}$

Throughout the course of the ongoing relationship between alumnus and alma mater, there comes a time when he or she may be more responsive to this form of alumni/ donor engagement. This phase usually occurs later in life, after retirement, or at a time when careers appear to be winding down. It might be a time when their children have moved on, and they are prone to be more nostalgic or reflective about life in general, and their college life in particular.

This is the time when the university archivist, as well as the institution's devel- opment and advancement teams, need to be prepared to reach out to its alumni for assistance and support. For foundation and development officers, this means financial support. For the archivist, however, that assistance takes the form of donations of artifacts and memorabilia from their years at the school. Once alumni have reached this juncture in their lives, and once they are made aware of the university archivist's desire for their materials and its mission to document and preserve the history of the school, they are easy to bring onboard. ${ }^{2}$

This type of engagement with alumni offers a twofold purpose. It provides alumni with the opportunity to reconnect and give back to the school where they earned their degrees and spent some of their happy and formative years. It also dovetails nicely with the trend in modern university archives to collect materials from former students to help document the student experience at the school.

College and university archivists are learning that, while a university records management program is important, it only tells half of the story of the school. For the institution to be chronicled to its fullest effect, the social and cultural side must

Eddie Woodward is archives coordinator, Sargeant Memorial Collection, Norfolk Public Library, email: eddiebud1@yahoo.com

๑ 2015 Eddie Woodward 
be documented as seen through the eyes of the students who attended the school. Just as social history was a reaction to the old school historiography that documented the institution from the top, or administration down, this historiographical approach serves to chronicle the college or university from the bottom, or student body, up. This desire to record student social and cultural history presents an opportunity for mutually beneficial engagement for both the school and its former students.

In order to get them interested in the program, alumni must first be made aware that the university archive exists, and what its mission entails. Logical, thoughtful, and, most importantly, strategic efforts in publicizing the desire for materials that document the student experience will help to build the collection quickly. This type of outreach can take many forms, some of which are an archive newsletter, articles in the local newspaper, mentions in an alumni-orientated publication, or though collaborative events and other ventures with the alumni association, the college or university foundation, or other campus advancement/development entities.

Although alumni engagement should be far-reaching, college and university towns always have a strong nucleus of former students. Appeals for donations that reach local alums, whether they are in the archives newsletter, other university publications, or in the local newspaper, always result in a flurry of communications, and ultimately donations. These local alumni are usually some of the first to get involved, and they will ultimately serve as agents or ringleaders to bring others into the fold.

As sometimes happens, when alumni learn of the archives and its mission, they often believe that their materials would be of no use to the school- that either the university archives already has copies of everything or that their items would be too personal or trivial for inclusion. The materials that were retained (or personally archived) by the former students were important enough for them to save for any number of reasons, and reflect the personal tastes and interests of the student. These time capsules that help to document their four or five years on the campus, form the student/alumni collections that serve to chronicle the social and cultural history of the college or university.

Once alumni know of their alma mater's desire for their materials, they may react in different ways. Some, with strong emotional attachments to their school, cling to their memorabilia with a promise to leave it to the archive at some point. They understand the importance of the college or university archive in documenting the history of the school and look forward to being a part of that history. Sometimes they require a little cajoling, and in these cases, sometimes all that is needed are some small incentives. These might include simple inducements like mentions in the newsletter, making the photographs available online, or naming the collection after them with an online finding aid. (These naming conventions are a special incentive and are especially important to relatives of deceased alums.)

Campus or museum exhibition potential is another incentive that may put those teetering over the hump. However, more often than not it is easier than all this. A large portion of alumni are relieved to find that the university archive wants their materials because they fear that no one in their family would want or appreciate them. For them, there is a sense of satisfaction in knowing that they are helping to document the history of their school, and that their college or university memorabilia will be cared for and preserved and be made accessible for future researchers.

It is through this act of donating, or giving back to their alma mater, that they become invested in the university archive, giving them a sense of ownership in the project and making them stakeholders in its success. This feeling of ownership very often leads to future donations, both in artifacts and financial support. It also provides an unintended benefit, as it sometimes motivates these 
alumni to begin to promote the archive to their former classmates, and in this scenario, they frequently serve as agents for the archive, rounding up more materials to help build and grow the collection. These alumni know more than anyone what materials are out there, who may have them, and what is needed to more thoroughly document their own personal student experiences.

The late archives scholar Terry Cook recognized this form of "participant and partner" alumni engagement as the next phase in archivists' appraisal evolution. Within this framework, Cook saw archivists as ready to share the appraisal function with their constituents, "where we engage our expertise with theirs in a blend of coaching, mentoring, and partnering." 3

Some alumni, especially those who have few or no artifacts or memorabilia to donate but still want to participate in the project, can get involved in other ways. For example, they can contribute memories of their time on campus via oral record, which can provide added value to the archive in unconventional ways.

All college and university archives have large photograph collections with little or no textual information. Alumni, with their social, cultural, and institutional knowledge, can provide an invaluable contribution by helping to identify the people, places, and events depicted in the photographs from their particular eras. And they gain a sense of pride in understanding the importance of their historical knowledge in chronicling their time on the campus.

Additionally, creating a college/campus historical society in combination with a historical lecture series can bring together alumni of all ages with the current student population. These opportunities can help alumni (as well as former faculty and staff) without memorabilia feel a sense of ownership in the university archives, its mission, and its overall success.

\section{Conclusion}

College and university alumni very often want to engage or re-engage with their alma mater. Many times, however, it is not because of disinterest that they are not involved, but it is often because of distance or proximity to their school, or lack of awareness of the university archives and its mission.

When alumni learn of the project, and then donate, they are joining with the archivists and other alumni in their efforts to document the history of their school. And in doing so, they feel a sense of pride as stakeholders, and a sense of ownership in the project and its ultimate success.

College and university archives can help to build this sense of community with their alumni through their joint passion for the school, and their commitment to the university archive and its mission to document and preserve the history of their alma mater.

\section{Notes}

1. David X. Cheng, "Students' Sense of Campus Community: What it Means, and What to do About It," NASPA Journal 41, no. 2 (Winter 2004), 222, 229; Anthony Dean McAdoo, "Factors Affecting the Institutional Perception of Alumni of the University of Arkansas" (PhD dissertation, University of Arkansas, 2010), 90.

2. Institutional advancement scholar, Maria L. Gallo has outlined the four stages of the alumni relationship building cycle as: affiliation, affinity, engagement, and support. Within this framework, alumni appear to be the most susceptible to engagement or re-engagement during the last two phases: engagement and support. Maria L. Gallo, "Higher Education Over a Lifespan: a Gown to Grave Assessment of a Lifelong Relationship Between Universities and Their Graduates," Studies in Higher Education 38, no. 9 (2013), 1150-1161.

3. Terry Cook, "We Are What We Keep; We Keep What We Are': Archival Appraisal Past, Present and Future," Journal of the Society of Archivist 32:2 (October 2011), 182-183. 